\title{
SOURCES OF INFECTION WITH PSEUDOMONAS AERUGINOSA IN PATIENTS WITH TRACHEOSTOMY
}

\author{
E. J. L. Lowbury, B. T. Thom, H. A. LiLly, J. R. Babb AND \\ K. WhitTALL \\ MRC Industrial Injuries and Burns Research Unit, Birmingham Accident Hospital, and \\ the Central Public Health Laboratory, Colindale, London
}

THE respiratory tract of patients with tracheostomy often becomes infected with Pseudomonas aeruginosa (Ps. pyocyanea).

In many cases this appears to have no pathological effect; in others, however, illness and death due to infection of the broncho-tracheal tree take place and such infection is recognised to be a major hazard of tracheostomy (Bishop, Potts and Molloy, 1962; Dupont, Lissac and Amstutz, 1962; Gotsman and Whitby, 1964; Watts, 1964; Phillips, 1967). The special importance of contamination with $P_{s}$. aeruginosa from respiratory ventilators has been described by Phillips and Spencer (1965), and efforts have been made to reduce this hazard by adequate disinfection of the apparatus before use (Bishop et al.; Alder, Brown and Gillespie, 1966; Bishop, 1966; Tinne et al., 1967; Judd et al., 1968). In a study of 18 patients treated with tracheostomy and mechanical ventilation, Phillips reported the occurrence of infection in 12 and found respiratory ventilators to be the only common source. Other sources of infection have, however, been reported and found important, e.g., aspirators and solutions used for suction (Sutter et al., 1966).

In this paper we report a 20 months' study on the sources of post-tracheostomy infection with Ps. aeruginosa in an intensive care unit for patients with major injuries. A variety of probable sources and routes of transfer was shown with the aid of typing methods. The problems of controlling such infections are discussed.

\section{MATERIALS AND METHODS}

The Major Injuries Unit

This Unit (London, 1961) consists of two adjoining open wards, connected by an open doorway. One ward is for the reception, diagnosis and initial treatment of severely injured patients. The other ward is specially equipped for the further care of survivors, and has four beds, each provided with oxygen, suction and pressure gauges, and with the equipment needed for infusion, resuscitation, respiratory ventilation and humidification. The beds are separated by curtains, and there is adequate space for movement of staff and equipment. There is no mechanical ventilation of the wards.

In addition to these two wards, there is a small ward (Tracheostomy Ward) in another part of the hospital containing three beds in cubicles, with plenum ventilation, for prolonged treatment of patients with tracheostomy who are transferred to it from the main ward of the Major Injuries Unit. The Tracheostomy Ward has a separate nursing staff, but some members of the hospital staff work in both areas. In this report the Major Injuries and Tracheostomy Wards will be described collectively as the Major Injuries Unit (MIU).

Received 20 Mar. 1969; accepted 30 June 1969.

J. MED. MICROBIOL.—VOL. 3 (1970) 


\section{Infection of patients with Ps. aeruginosa}

Between Jan. 1966 and Aug. 1967, patients with tracheostomy had frequent, often daily, samples of tracheal sputum taken on cotton-wool swabs. From many patients oral swabs were taken at the same time, and rectal swabs were taken soon after admission, and sometimes also later. Nasopharyngeal swabs also were taken from some of the patients. Swabs were examined for the presence of Ps. aeruginosa by inoculation on to 0.03 per cent. cetrimide agar (Brown and Lowbury, 1965) and into Robertson's cooked meat broth. In the early part of the study many swabs were also inoculated on to horse blood agar. After incubation at $37^{\circ} \mathrm{C}$ for $24 \mathrm{hr}$, the culture plates were examined for Ps. aeruginosa by detection of pigments and fluorescence on cetrimide agar (Lowbury, Lilly and Wilkins, 1962). Cooked meat broth cultures were subcultured after 48 hours' incubation to "spot-plates " of cetrimide agar, which were examined for the presence of Ps. aeruginosa by the methods mentioned above. Supporting and confirmatory tests, namely those for the oxidase reaction, pyocyanin production and growth at $42^{\circ} \mathrm{C}$ (Brown and Lowbury) were applied to a proportion (75 strains) of presumptive isolates of Ps. aeruginosa. Most of the strains were typed by the serological and phage typing methods described below.

\section{Ps. aeruginosa in the environment}

Bacteriological studies were made weekly in the MIU. Samples were taken from the hands of all members of the staff on duty, including nurses, doctors, physiotherapists and cleaners, and from a large number of sites in the inanimate environment, including floors, furniture, equipment, sinks and food. This programme of sampling was carried out during periods when patients infected with Ps. aeruginosa occupied the MIU ("outbreaks") and was continued during periods when there were no patients with $P$ s. aeruginosa in either ward. Air samples, on the other hand, were taken only on visits at the beginning of the study while patients infected with $P$ s. aeruginosa were in the MIU.

Sampling methods. From most sources (e.g., floors, sinks, suction apparatus and ventilators), samples were taken with absorbent cotton-wool swabs, which were moistened with peptone water when the sample was from a dry surface. Hands were sampled by a standard washing with $100 \mathrm{ml}$ nutrient broth (Lowbury and Lilly, 1960); the broth was plated immediately and again after 24 hours' incubation at $37^{\circ} \mathrm{C}$ on to cetrimide agar. Air samples (138 cu. ft, i.e., 3905 litres) were taken with a large slit sampler on to cetrimide agar. All samples were examined for Ps. aeruginosa.

Respiratory ventilators. In addition to the bacteriological samples taken during the weekly visits to the MIU, special samples were taken on 20 occasions from the Smith-Clarke ventilator ( 85 samples), on 21 occasions from the East-Radcliffe ventilator (66 samples), and on 5 occasions from the East-Freeman ventilator (15 samples). Samples were taken in this series from expiratory and inspiratory tubing, circuit, humidifiers, Y-pieces and tracheal connectors; also from condensate, water-traps, spirometers, humidifier reservoirs, catheter mounts, positive and negative bellows and air effluent.

Blower-humidifiers. Sixty-four samples were taken; the sites sampled were tubing, vaporising block, reservoir, condensate and air effluent (see below).

\section{Typing of Ps. aeruginosa}

Most of the strains of $P_{s}$. aeruginosa from patients and a large proportion of the strains from the staff and the inanimate environment were typed serologically and their phagetyping patterns were determined.

Serological typing. The method of typing was based on the scheme of Habs (1957) who described twelve serological types differentiated by heat-stable antigens. It resembled closely the method used in epidemiological studies by Wahba (1965) and Shooter et al. (1966). Our serological classification includes thirteen O types (1-13) and two of Véron's subtypes of Habs' types 2 and 5 (Véron, 1961). We adopted the nomenclature of Véron, in which Habs' types 2 and 5 are designated $2 \mathrm{a}$ and $5 \mathrm{c}$, respectively, and the Véron subtypes 
are $2 \mathrm{~b}$ and $5 \mathrm{~d}$. In addition, serotype 6 was subdivided by means of heat-labile antigens into subtypes $6 \mathrm{a}, 6 \mathrm{~b}$ and $6 \mathrm{c}$. The sera used for this purpose were prepared against formolised suspensions of the following organisms: for type 6a, the type strain Habs' type 6; for type 6b, the strain Fr31 (Verder and Evans, 1961); for type 6c, the type strain for Wahba's type 14 (Wahba).

Cultures were typed by slide agglutination after overnight growth at $30^{\circ} \mathrm{C}$ on nutrient agar plates. The strains were first tested with four pools of antisera, then with individual antisera. The antisera were used at a concentration four times greater than that giving strong agglutination with the homologous serotype. Any strains that failed to agglutinate in the pooled antisera, or showed cross-reactions between pools, were subcultured, and suspensions of organisms boiled for $2 \mathrm{hr}$ were tested by slide agglutination.

Phage typing. The method used was as described by Shooter et al. In addition to the 18 phages used by these authors, two phages isolated at Colindale, Col. 11 and Col. 18, were included.

\section{Use of respiratory ventilators and blower-humidifiers}

A record kept during the first four periods of the study (Jan. 1966 to early Apr. 1966) showed 19 patients in the MIU who had tracheostomies; all 19 were treated at some time with a blower-humidifier, and 6 were treated with a respiratory ventilator. As there was little association between infection with $P$ s. aeruginosa and the use of ventilators, this special record was discontinued after Apr. 1966.

\section{Control of infection}

On the basis of findings made in the course of the study, attempts were made to control infection by the introduction of some improvements in aseptic technique. These changes were introduced at different times when probable sources of infection were found. In period 1, disposable plastic gloves were introduced for as many as possible of the routine nursing activities that involved contact with patients. In period 5 , the concentration of chlorhexidine was increased from 0.02 to 0.5 per cent. for use in suction aspirator jars and for nailbrushes. Individual washing bowls were introduced for all patients in period 10. Sterile disposable catheters were used for aspiration of mucus from the trachea and bronchi throughout the study.

Sterile supplies. Dressing packs were prepared in the MIU and sterilised in a pressure steam steriliser in the hospital. Instruments, receivers and surgical bowls were sterilised in a Speedomatic high-pressure instrument and small bowl steriliser (G.U. Sterilizers Ltd).

Disinfection of mechanical respiratory ventilators. After use, the inspiratory and expiratory tubes, connexions and water-traps were washed and then immersed for $2 \mathrm{hr}$ in an aqueous solution of 0.5 per cent. chlorhexidine gluconate. The temperature in the humidifiers was raised and held for $1 \mathrm{hr}$ at $100^{\circ} \mathrm{C}$ in the East-Radcliffe and East-Freeman ventilators and at $88^{\circ} \mathrm{C}$ in the Smith-Clarke ventilator; the humidifier was then emptied and filled with tap water. After disinfection and reassembly, swabs were taken from the breathing tubes, water-traps and humidifiers; Ps. aeruginosa was never found in these tests.

Disinfection of blower-humidifiers. From period 2, the tube and connexions supplying humidified air were immersed, after use on a patient, in 0.5 per cent. chlorhexidine gluconate solution. The porcelain vaporising block was sterilised in a pressure steam steriliser at $130^{\circ} \mathrm{C}$. The chamber and reservoir of the humidifier were washed out with $0 \cdot 5$ per cent. chlorhexidine gluconate solution, and kept dry during storage. In the first period of the study, 0.02 per cent. chlorhexidine gluconate was used for disinfection and the humidifier was stored with water in the chamber and reservoir.

Disinfection of suction apparatus. The rubber tubing, collection jars and connexions were sterilised daily in a pressure steam steriliser. From period 5 the collection jars contained $120 \mathrm{ml}$ of 0.5 per cent. chlorhexidine gluconate solution. In the early part of the study the concentration of chlorhexidine gluconate was 0.02 per cent.

Disinfection of other equipment. Important shortcomings were found; some of these were rectified (see below), but for others no satisfactory improvements were introduced during the 
study, because of shortage of space and other difficulties. Wash bowls. In the early part of the study communal bowls were used, and stored for re-use in the sluice room after a thorough rinse but without disinfection. Later, each patient was given his own bowl, which was boiled for 20 min. every day. Bedpans. A mechanical bedpan washer (Dent and Hellyer) was used; although the washer was provided with a steam jet, this was not functioning properly, and the equipment could not be assumed to achieve disinfection. Urinals. These were thoroughly washed with soap and water, but in the earlier part of the study they were not disinfected. Later, individual bottles provided for patients were boiled every day. Nailbrushes were autoclaved daily, and kept in chlorhexidine solution (initially 0.02 per cent., later 0.5 per cent.). Catheters were disposable. Crockery was washed in the kitchen with soap and water; no dish washer was available. Floors were cleaned several times a day with

\section{TABLE I}

Duration of tracheostomy and occurrence of infection with Pseudomonas aeruginosa in 63 patients* treated by tracheostomy out of 1032 patients $\dagger$ admitted to the MIU between Jan. 1966 and Aug. 1967

\begin{tabular}{|c|c|c|c|}
\hline $\begin{array}{l}\text { Duration of } \\
\text { tracheostomy } \\
\text { (days) }\end{array}$ & $\begin{array}{l}\text { Number of patients } \\
\text { with tracheostomy } \\
\text { during the period } \\
\text { stated }\end{array}$ & $\begin{array}{l}\text { Number of } \\
\text { patients whose tracheas } \\
\text { became infected with } \\
\text { Ps. aeruginosa } \\
\text { during the period stated }\end{array}$ & $\begin{array}{c}\text { Number of days after } \\
\text { tracheostomy operation } \\
\text { on which Ps. aeruginosa } \\
\text { was first isolated } \\
\text { from tracheal swab }\end{array}$ \\
\hline $\begin{array}{c}1-3 \\
4-7 \\
8-14 \\
15-21 \\
22-28 \\
29-\end{array}$ & $\begin{array}{l}63 \\
48 \\
35 \\
21 \\
13 \\
11\end{array}$ & $\begin{array}{l}9 \\
9 \\
1 \\
0 \\
0 \\
2\end{array}$ & $\begin{array}{c}0,1,1,2,2,2,2,3,3 \\
4,5,5,5,6,6,6,7,7 \\
10 \\
\ldots \\
29,35\end{array}$ \\
\hline Any duration & 63 & 21 & $\ldots$ \\
\hline
\end{tabular}

* Excluding patients whose tracheostomies were established before the study began.

$\dagger$ The length of stay of all admissions in the MIU was $<24 \mathrm{hr}$ for 681 patients, $1-5$ days for 227 , 6-10 days for $57,11-21$ days for $34,3-6 \mathrm{wk}$ for 22 , and longer than $6 \mathrm{wk}$ for 11 .

$\ddagger$ Swabs were taken frequently, often daily, from day of admission (day 0 ).

a detergent and water. Waterproof sheets. Disposable plastic sheets were used, separate ones for each patient. Mattresses were covered with plastic envelopes which were thoroughly cleaned with 0.05 per cent. chlorhexidine on discharge of patients. Skin. Patients were washed with soap and water with their own flannel cloth. Hexachlorophane soap was used by nurses, and 0.5 per cent. chlorhexidine in 70 per cent. ethyl alcohol was used for preoperative disinfection. Sputum mugs were disposable.

\section{RESULTS}

\section{Acquisition of Ps. aeruginosa by patients with tracheostomy}

Table I shows details about the 1032 patients admitted to the Major Injuries Unit between Jan. 1966 and Aug. 1967. Of the 63 patients with tracheostomies, 21 acquired infection of the respiratory tract with $P$ s. aeruginosa. One patient was admitted with a tracheostomy and was already infected with Ps. aeruginosa. In the others $P$ s. aeruginosa appeared for the first time at intervals ranging from 1 to 35 days after the tracheostomy operation. 
Interpretation of typing of Ps. aeruginosa

Eighteen distinct strains of Ps. aeruginosa were recognised, of which 11 were isolated on two or more occasions. The serotype and phage-typing pattern of these 11 strains are shown in table II. Code letters have been applied to them to simplify the tables that follow. The phage-typing patterns are given as a list of the phages that caused strong lysis (i.e., more than 50 plaques), although the presence of weaker reactions was taken into account in determining similarities between cultures. Constant reactions were those given by all isolates and variable reactions were those given by 50 per cent. or more of the isolates of a particular strain.

TABLE II

Serological type and phage-typing pattern of 11 strains of Ps. aeruginosa designated by the code letters $A-K$

\begin{tabular}{|c|c|c|c|}
\hline \multirow{2}{*}{$\begin{array}{l}\text { Code designation } \\
\text { of strain }\end{array}$} & \multirow{2}{*}{$\begin{array}{l}\text { Serological } \\
\text { type }\end{array}$} & \multicolumn{2}{|c|}{ Phage-typing pattern* at RTD } \\
\hline & & Constant & Variable \\
\hline $\begin{array}{l}\text { A } \\
\text { B } \\
\mathbf{C} \\
\mathbf{D} \\
\mathrm{E} \\
\mathbf{F} \\
\mathrm{G} \\
\mathbf{H} \\
\mathbf{J} \\
\mathbf{K} \\
\mathbf{L}\end{array}$ & $\begin{array}{l}6 \mathrm{~b} \\
2 \mathrm{a} \\
6 \mathrm{c} \\
2 \mathrm{a} \\
1 \\
5 \mathrm{c} \\
5 \mathrm{~d} \\
6 \mathrm{a} \\
1 \\
9 \\
2 \mathrm{~b}\end{array}$ & $\begin{array}{l}7 / 73 \\
109 / 1214 \\
7 \\
21 / \mathrm{Col} .21 \\
7 / 21 / 68 / 109 / 352 \\
7 \\
\text { NT }(119 x) \dagger \\
7 / 68 / 109 / 119 x / \text { Col. } 11 \\
7 / 44 \\
21 / 24 / 31 / 68 / 119 x / \text { Col. } 11 \\
21 / 68\end{array}$ & $\begin{array}{l}\text { 31, 109, M4 } \\
\text { 16, 44, F8 } \\
\text { 68, F7 } \ldots \\
\text { F8, M4, 119x, Col. } 11 \\
\text { 31, F7 } \\
\text { 16, 21, 24, M4, Col. } 18 \\
68 \\
44, \mathrm{~F} 8,109,1214 \\
31\end{array}$ \\
\hline
\end{tabular}

* The pattern is stated as the numbers of the phages giving strong lysis of the bacteria. Constant reactions were given by all isolates of the strain and variable reactions by over 50 per cent. of strains, but not by all of them.

$\dagger$ Not typable at routine test dilution (RTD) of phage, but reaction obtained with phage $119 \mathrm{x}$ at $100 \times$ RTD.

Strains that gave different serological reactions were considered to be distinct even when the phage-typing patterns were similar (e.g., strains D and L). Strains that were serologically indistinguishable were regarded as distinct if there were marked differences in the phage-typing pattern (e.g., strains B and $\mathrm{D}$, strains $\mathrm{E}$ and $\mathrm{J}$ ). Strain A was the strain most frequently encountered and it showed some variation in its phage-typing pattern, although it usually gave a wide pattern of four strong reactions and several additional weak reactions.

\section{Types of Ps. aeruginosa in patients and the environment}

Table III shows the number of patients with tracheostomy in whom the trachea became infected with one or more types of Ps. aeruginosa; eight "outbreaks" occurred, with intervening periods during which no patients had Ps. aeruginosa infection of a tracheostomy. 
Table IV shows the types of $P s$. aeruginosa isolated from tracheostomies, from other sources (mouth, sputum, urine, rectum, wounds) in patients, from the environment, and from patients in other wards, with the dates of first isolation of each strain. Successive outbreaks were usually due to different types of $P$ s. aeruginosa. In five outbreaks more than one type was found. Ps. aeruginosa of types causing infection was usually found on the hands of staff, including nurses, doctors, physiotherapists and cleaners, and in the

TABLE III

Patients with tracheostomies from which Ps. aeruginosa was isolated

\begin{tabular}{|c|c|c|c|}
\hline \multirow[b]{2}{*}{ Period no. } & \multirow[b]{2}{*}{ Dates of period } & \multicolumn{2}{|c|}{ Numbers of patients admitted in period who } \\
\hline & & underwent tracheostomy & $\begin{array}{l}\text { became infected in } \\
\text { trachea with } P s \text {. aeruginosa } \\
\text { (and type of strain*) }\end{array}$ \\
\hline $\begin{array}{r}1 \\
2 \\
3 \\
4 \\
5 \\
6 \\
7 \\
8 \\
9 \\
10 \\
11 \\
12 \\
13 \\
14 \\
15\end{array}$ & $\begin{array}{l}\text { 4 Jan.-10 Feb. } 1966 \\
\text { 11-27 Feb. } \\
28 \text { Feb.-14 Apr. } \\
15 \text { Apr.-28 June } \\
29 \text { June-23 Aug. } \\
24 \text { Aug.-6 Oct. } \\
7 \text { Oct.-31 Dec. } \\
\text { 1-24 Jan. } 1967 \\
25 \text { Jan.-24 Feb. } \\
25 \text { Feb.-19 March } \\
20 \text { March-24 Apr. } \\
25 \text { Apr.-14 May } \\
15 \text { May-27 June } \\
28 \text { June-27 July } \\
28 \text { July-18 Aug. } 1967\end{array}$ & $\begin{array}{r}10 \dagger \\
5 \\
1 \\
7 \\
1 \\
13 \\
17 \\
1 \\
3 \\
2 \\
4 \\
2 \\
6 \\
0 \\
1\end{array}$ & $\begin{array}{l}8(7 \mathrm{~A}, 2 \mathrm{~B}) \\
0 \\
1(\mathrm{~B}) \\
0 \\
1(\mathrm{E}) \\
0 \\
9(1 \mathrm{~A}, 5 \mathrm{~F}, 1 \mathrm{~L}, 2 \mathrm{NT}) \\
0 \\
3(2 \mathrm{~A}, 1 \mathrm{~F}, 2 \mathrm{G}, 1 \mathrm{~L}) \\
0 \\
3(2 \mathrm{~F}, 1 \mathrm{X}) \\
0 \\
3(1 \mathrm{~A}, 1 \mathrm{D}, 1 \mathrm{~K}) \\
0 \\
1(\mathrm{E})\end{array}$ \\
\hline
\end{tabular}

* Figures in brackets show the numbers of patients carrying strains of the types indicated by the capital-letter codes. Some patients were infected with more than one type. $\mathrm{X}=$ Uncoded type. NT $=$ Not typed.

+ Patients whose tracheostomies were established when study began.

inanimate environment (table IV). These bacteria of the epidemic type were more often isolated from such sources after than before their first isolation from tracheostomies, but in all except one of the outbreaks strains of an infecting type (shown in italics) were found in the environment or in other wards before or as soon as they appeared in tracheostomies. Presumptive sources and vectors of infection could therefore be postulated. In period 1, type-B infections and some of the later type-A infections could have come from the environment and type $B$ also from another ward (the Burns Unit). Type-B infection in period 3 could have been transferred from other patients in the MIU on the hands of nurses and possibly on other vectors (e.g., suction apparatus). In period 5, transfer on hands of staff again seemed likely, and there was a possibility of self-infection from oral and rectal carriage, though oral and rectal swabs taken on admission did not yield Ps. aeruginosa. In period 7, infection with type L might have come from the Burns Unit, and type A was probably acquired from the environment of the MIU on the hands of 
TABLE IV

Dates of the first isolation of strains of different types of Ps. aeruginosa from tracheostomies, other sites in patients, the hands of staff and the inanimate environment in the Major Injuries Unit (MIU) and other wards of the hospital during 15 consecutive periods between 1 Jan. 1966 and 18 Aug. 1967

\begin{tabular}{|c|c|c|c|c|c|}
\hline \multirow{4}{*}{ Period } & \multicolumn{5}{|c|}{$\begin{array}{c}\text { Types of } P \text { s. aeruginosa and date (day/mth) of its first isolation during } \\
\text { the period, in }\end{array}$} \\
\hline & \multicolumn{4}{|c|}{ MIU from } & \multirow{3}{*}{$\begin{array}{l}\text { other wards } \\
\text { of hospital }\end{array}$} \\
\hline & \multicolumn{2}{|c|}{ patients, from } & \multirow{2}{*}{$\begin{array}{l}\text { hands of } \\
\text { staff* }\end{array}$} & \multirow{2}{*}{$\begin{array}{l}\text { inanimate } \\
\text { environment }\end{array}$} & \\
\hline & tracheostomies & other sites & & & \\
\hline 1 & $\begin{array}{l}\text { A } 4 / 1 \\
\text { B } 14 / 1\end{array}$ & 0 & $\begin{array}{l}\text { A } 13 / 1 \\
B \quad 13 / 1 \\
\text { C } 27 / 1\end{array}$ & $\begin{array}{ll}\text { A } & 6 / 1 \\
B & 4 / 1 \dagger\end{array}$ & $\begin{array}{ll}B & 1 / 1 \dagger \\
\mathrm{D} & 7 / 1 \\
\mathrm{~L} & 1 / 1\end{array}$ \\
\hline 2 & 0 & 0 & $\begin{array}{l}\text { C } 18 / 2 \\
\text { H } 11 / 2\end{array}$ & $\begin{array}{l}\text { A } 11 / 2 \\
\text { C } 10 / 2\end{array}$ & $\begin{array}{rr}\text { A } & 26 / 2 \\
? B & 27 / 2 \\
\text { D } & 19 / 2 \\
\text { L } 25 / 2\end{array}$ \\
\hline 3 & B $3 / 3$ & $\begin{array}{ll}\mathrm{B} & 2 / 3 \\
\mathrm{H} & 2 / 3\end{array}$ & $\begin{array}{l}\text { B } 4 / 3 \\
\text { C } 14 / 4\end{array}$ & $\begin{array}{lr}\text { A } & 4 / 3 \\
\text { B } & 4 / 3 \\
\text { C } & 14 / 3\end{array}$ & A $21 / 3$ \\
\hline 4 & 0 & D $22 / 4$ & C $28 / 4$ & $\begin{array}{l}\text { A } 28 / 4 \\
\text { B } 28 / 4 \\
\text { C } 3 / 5\end{array}$ & $\begin{array}{l}\text { B } 15 / 6 \\
\text { D } 10 / 6 \\
\text { X } 25 / 6\end{array}$ \\
\hline 5 & E $1 / 7$ & E $29 / 6$ & $\begin{array}{ll}\text { C } & 1 / 7 \\
\text { E } & 1 / 7\end{array}$ & $\begin{array}{l}\text { A } \\
\text { C } \\
1 / 7\end{array}$ & NST \\
\hline 6 & 0 & J $30 / 9$ & A $30 / 8$ & $\begin{array}{l}\text { A } 30 / 8 \\
\text { J } 30 / 8\end{array}$ & $\begin{array}{ll}\mathrm{E} & 1 / 9 \\
F & 2 / 10\end{array}$ \\
\hline 7 & $\begin{array}{rr}\text { A } & 14 / 12 \\
\text { F } & 7 / 10 \\
\text { L } & 2 / 11 \\
\text { NT } & 5 / 11\end{array}$ & 0 & $\begin{array}{l}\text { A } 18 / 10 \\
\mathrm{~F}\end{array}$ & $\begin{array}{lr}A & 18 / 10 \\
\mathrm{~F} & 9 / 11 \\
\mathrm{~J} & 18 / 10 \\
\mathrm{X} & 9 / 11\end{array}$ & $\begin{array}{rr}A & 24 / 10 \\
\text { B } 25 / 10 \\
\text { D } 23 / 10 \\
\text { ?H } 27 / 10 \\
? \mathrm{~K} \quad 5 / 12\end{array}$ \\
\hline 8 & 0 & 0 & 0 & $A \quad 3 / 1 / 67$ & 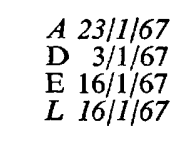 \\
\hline 9 & $\begin{array}{l}\text { A } 27 / 1 \\
F \quad 4 / 2 \\
\text { G } 2 / 2 \\
\text { L } 26 / 1\end{array}$ & $\begin{array}{ll}\mathrm{D} & 2 / 2 \\
\mathrm{~L} & 8 / 2\end{array}$ & $\begin{array}{l}\text { A } 30 / 1 \\
F 30 / 1 \\
G \quad 30 / 1 \\
\text { D } 30 / 1\end{array}$ & $\begin{array}{l}\mathrm{A} 30 / 1 \\
\mathrm{~F} \quad 8 / 2 \\
G \quad 30 / 1 \\
\mathrm{~L} 30 / 1 \\
\mathrm{X} 30 / 1\end{array}$ & $F 28 / 1$ \\
\hline
\end{tabular}


TABLE IV-continued

\begin{tabular}{|c|c|c|c|c|c|}
\hline \multirow{4}{*}{ Period } & \multicolumn{5}{|c|}{$\begin{array}{c}\text { Type of Ps. aeruginosa and date (day } / \mathrm{mth}) \text { of its first isolation during } \\
\text { the period in }\end{array}$} \\
\hline & \multicolumn{4}{|c|}{ MIU from } & \multirow{3}{*}{$\begin{array}{l}\text { other wards } \\
\text { of hospital }\end{array}$} \\
\hline & \multicolumn{2}{|c|}{ patients, from } & \multirow{2}{*}{$\begin{array}{l}\text { hands of } \\
\text { staff* }\end{array}$} & \multirow{2}{*}{$\begin{array}{l}\text { inanimate } \\
\text { environment }\end{array}$} & \\
\hline & tracheostomies & other sites & & & \\
\hline 10 & 0 & 0 & G $3 / 3$ & $\begin{array}{ll}F & 3 / 3 \\
\mathrm{~L} & 3 / 3\end{array}$ & $\mathrm{X} 13 / 3$ \\
\hline 11 & $\begin{array}{l}\mathrm{F} \quad 23 / 3 \\
\mathrm{X} 12 / 4\end{array}$ & 0 & $F 22 / 3$ & $\begin{array}{l}\text { A } 22 / 3 \\
F 22 / 3 \\
\text { G } 22 / 3\end{array}$ & D 20/3 \\
\hline 12 & 0 & 0 & NSE & NSE & $\begin{array}{cc}? \mathrm{~B} & 1 / 5 \\
\mathrm{X} & 1 / 5\end{array}$ \\
\hline 13 & $\begin{array}{l}\text { A } 15 / 6 \\
\text { D 20/5 } \\
\text { K } 16 / 5\end{array}$ & D $23 / 5$ & $\begin{array}{l}\text { D } 24 / 5 \\
\text { F } 24 / 5\end{array}$ & $\begin{array}{l}A 22 / 5 \\
\text { D } 22 / 5 \\
\text { F } 24 / 5 \\
\text { K } 24 / 5\end{array}$ & NST \\
\hline 14 & 0 & $\mathbf{0}$ & $E \quad 4 / 7$ & A $4 / 7$ & 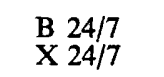 \\
\hline 15 & E $28 / 7$ & 0 & E $2 / 8$ & E $2 / 8$ & NST \\
\hline
\end{tabular}

* Staff examined included nurses, doctors, physiotherapists and cleaners.

+ Italics show Ps. aeruginosa isolated from the environment or from other wards within 60 days and usually in a shorter time before outbreaks of infection with the same type appeared in tracheostomies.

$\mathrm{NST}=$ No strains typed. $\mathrm{NSE}=$ No samples examined. $\mathrm{X}=$ Uncoded type. $\mathrm{NT}=$ Not typed.

nurses. In period 9, type-A infection could have come from the environment in the MIU (sink, wash-basin), type L from the Burns Unit, type G from the environment (suction tube, etc.) on the hands of nurses, and type $F$ from another ward on nurses' hands. The environment (wash-basin) and a nurse's hands were a likely source of type-F infection also in period 11 . One of the patients who had tracheostomy infection in period 13 had been transferred from another hospital with a strain of type K; during the same period there was an infection with type D probably acquired from the Burns Unit on nurses' hands and an infection with type A probably acquired from the environment of the MIU. In period 15 the infection with type $\mathrm{E}$ was probably acquired from a nurse who had this type on her hands in period 14 . Though Ps. aeruginosa was found in the inanimate environment during each of the six periods when samples were taken between outbreaks, in only three of 
these periods did the strains isolated from the environment belong to the same type as a strain that caused infection during the next outbreak. In 5 of the periods between outbreaks Ps. aeruginosa was isolated from the hands of staff; two of these isolates were of the same type as one of those that caused infection in the subsequent outbreak.

In contrast with the types causing tracheal infection, those that were isolated from the inanimate environment included an endemic strain (type A) which was present in 12 of the 14 periods in which samples were taken from the

TABLE V

Isolations of different types of Ps. aeruginosa from wash-hand basins and other sinks* in the Major Injuries Unit during 15 consecutive periods between 1 Jan. 1966 and 18 Aug. 1967

\begin{tabular}{c|l|c|l}
\hline Period & $\begin{array}{c}\text { Type(s) of Ps. aeruginosa } \\
\text { infecting tracheostomies }\end{array}$ & $\begin{array}{c}\text { Number of samples* } \\
\text { taken from sinks and } \\
\text { wash-hand basins }\end{array}$ & $\begin{array}{c}\text { Type(s) of Ps. aeruginosa } \\
\text { isolated from wash-hand } \\
\text { basins and other sinks (and } \\
\text { number of samples yielding } \\
\text { each type) }\end{array}$ \\
\hline 1 & A, B & & A (1), NT (1) \\
2 & None & 20 & A (4), C (1)) X (2), NT (17) \\
3 & B & 60 & A (5), C (2), X (2), NT (5) \\
4 & None & $21,17^{*}$ & A (3), B (1), C A (1), B (2) \\
5 & E & 33,1 & A (4), C (2), NT (9), NT (I) \\
6 & None & 10 & A (4), J (1) \\
7 & A, F, L & 29 & A (15), F (1) \\
8 & None & 9 & A (5), F (2), X (1) \\
9 & A, F, G, L & 11 & A (4) Famples \\
10 & None & 0 & A (4), X (1), NT (1) \\
11 & F, X & 11 & No samples \\
12 & None & 0 & A (8), A (I) \\
13 & A, D, K & $21, I$ & A (7), A (6) \\
15 & None & 9,9 & E (1), NT (4), NT (1) \\
\hline
\end{tabular}

* Swabs from inner surface of basins are shown in italics; other results are from outlets. $\mathrm{NT}=$ Not typed. $\mathrm{X}=$ Uncoded types.

inanimate environment. The principal sources of type A strains were the washhand basins and other sinks. Samples were taken from the outlet and, on some occasions, also from the inner surfaces of the basins. The results, which are given in table $\mathrm{V}$, show that these sources contained the endemic strain of type $\mathrm{A}$ and also transient strains of other types that were isolated from the trachea or other sites in patients in the MIU. A large proportion of samples taken from sinks and wash-hand basin outlets were contaminated with Ps. aeruginosa. Tracheal infection with type A was predominant in period 1, and also took place in three other periods.

The collective results of sampling other environmental sites from which $P$ s. aeruginosa was isolated are shown in table VI. With the exception of plastic washing bowls, the sites tested were usually free from $P_{s}$. aeruginosa during periods between outbreaks, and such bacteria as were present were of the same type as the strain causing infection in the previous outbreaks. Many sites 


\section{TABLE VI}

Isolation of Ps. aeruginosa from different sources in the inanimate environment in the Major Injuries Unit during outbreaks of tracheostomy infections and in periods between outbreaks

\begin{tabular}{|c|c|c|c|c|c|c|}
\hline \multirow{3}{*}{ Source sampled } & \multicolumn{6}{|c|}{$\begin{array}{l}\text { Number of samples examined from source during outbreaks of trache- } \\
\text { ostomy infection (and number examined in periods between outbreaks) }\end{array}$} \\
\hline & \multirow[b]{2}{*}{ Total } & \multicolumn{4}{|c|}{ yielding $P s$. aeruginosa of } & \multirow[b]{2}{*}{$\begin{array}{l}\text { undeter- } \\
\text { mined } \\
\text { type }\end{array}$} \\
\hline & & any type & $\begin{array}{c}\text { type causing } \\
\text { infection in } \\
\text { current } \\
\text { outbreak }\end{array}$ & $\begin{array}{c}\text { type causing } \\
\text { infection in } \\
\text { previous } \\
\text { outbreak }\end{array}$ & $\begin{array}{l}\text { type not } \\
\text { causing } \\
\text { infection }\end{array}$ & \\
\hline $\begin{array}{l}\text { Humidifiers } \\
\text { (reservoir and tubing) }\end{array}$ & $64(23)$ & $6(1)$ & 4 & $0(1)$ & $0(0)$ & 2 \\
\hline Tubing of respirators & $11(1)$ & $3(0)$ & 1 & $0(0)$ & $0(0)$ & 2 \\
\hline Suction tubes & $114(37)$ & $9(0)$ & 6 & $0(0)$ & $0(0)$ & 3 \\
\hline $\begin{array}{l}\text { Aspirator bottles } \\
\text { collecting sputum }\end{array}$ & $102(32)$ & $12(0)$ & 5 & $0(0)$ & $0(0)$ & 7 \\
\hline Suction nozzles & $70(26)$ & $3(0)$ & 0 & $0(0)$ & $0(0)$ & 3 \\
\hline $\begin{array}{l}\text { Suction pump vent } \\
\text { holes }\end{array}$ & $72(22)$ & $2(0)$ & 1 & $1(0)$ & $0(0)$ & 0 \\
\hline $\begin{array}{l}\text { Oxygen resuscitation } \\
\text { masks }\end{array}$ & $25(7)$ & $1(0)$ & 1 & $0(0)$ & $0(0)$ & 0 \\
\hline Ventilation outlet grills & $32(4)$ & $1(0)$ & 1 & $0(0)$ & $0(0)$ & 0 \\
\hline Air samples & $22(0)$ & $3 *(0)$ & 2 & $0(\ldots)$ & $0(\ldots)$ & 1 \\
\hline Floor samples & $81(21)$ & $22(0)$ & 10 & $0(0)$ & $2(0)$ & 10 \\
\hline Floor mops & $25(2)$ & $3(0)$ & 2 & $0(0)$ & $0(0)$ & 1 \\
\hline $\begin{array}{l}\text { Draining board in } \\
\text { kitchen }\end{array}$ & $7(1)$ & $1(0)$ & $\overline{1}$ & $0(0)$ & $0(0)$ & 0 \\
\hline Vases of flowers & $3(1)$ & $1(0)$ & 0 & $0(0)$ & $1(0)$ & 0 \\
\hline Plastic washing bowls & $50(34)$ & $8(7)$ & 7 & $1(7)$ & $0(0)$ & 0 \\
\hline $\begin{array}{l}\text { Bars of soap and } \\
\text { soap dishes }\end{array}$ & $32(9)$ & $3(1)$ & 1 & 1 (1) & $1(0)$ & 0 \\
\hline $\begin{array}{l}\text { Nailbrushes in } 0.02 \\
\text { per cent. chlorhexi- } \\
\text { dine }\end{array}$ & $40(15)$ & $3(1)$ & 0 & $1(1)$ & $2(0)$ & 0 \\
\hline Sink mops & $12(4)$ & $4(0)$ & 1 & $1(0)$ & $0(0)$ & 2 \\
\hline Saucepan cleaners & $7(2)$ & $1(0)$ & 1 & $0(0)$ & $0(0)$ & 0 \\
\hline Dish cloths & $3(0)$ & $1(0)$ & 1 & $0(\ldots)$ & $0(\ldots)$ & 0 \\
\hline $\begin{array}{l}\text { Syringes in dishes, } \\
\text { used for feeding }\end{array}$ & $2(0)$ & $1(0)$ & 1 & $0(\ldots)$ & $0(\ldots)$ & 0 \\
\hline Food mixer & $15(3)$ & $4(0)$ & 2 & $1(0)$ & $0(0)$ & 1 \\
\hline Mixed food & $6(0)$ & $2(0)$ & $\mathbf{1}$ & $0(\ldots)$ & $1(\ldots)$ & 0 \\
\hline $\begin{array}{l}\text { Tooth brushes of } \\
\text { patients }\end{array}$ & $10(1)$ & $3(0)$ & 2 & $1(0)$ & $0(0)$ & 0 \\
\hline $\begin{array}{l}\text { Shaving kits of } \\
\text { patients }\end{array}$ & $2(0)$ & $1(0)$ & 0 & $1(\ldots)$ & $0(\ldots)$ & 0 \\
\hline $\begin{array}{l}\text { Mouth-water con- } \\
\text { tainers }\end{array}$ & $10(0)$ & $1(0)$ & 1 & $0(\ldots)$ & $\mathbf{0}(\ldots)$ & 0 \\
\hline $\begin{array}{l}\text { Protective felt cuffs } \\
\text { (one sample from } 2 \\
\text { cuffs) }\end{array}$ & $1(0)$ & $1(0)$ & 1 & $0(\ldots)$ & $0(\ldots)$ & 0 \\
\hline Nurses' uniforms & $7(0)$ & $1(0)$ & 1 & $0(\ldots)$ & $0(\ldots)$ & 0 \\
\hline Bed rails & $21(0)$ & $1(0)$ & 1 & $0(\ldots)$ & $0(\ldots)$ & 0 \\
\hline
\end{tabular}

* Three colonies on one plate and one on each of the other plates. 
were contaminated with $P s$. aeruginosa during outbreaks, usually with the type causing current infections.

Of 19 consecutive patients with tracheostomies in the early part of the study (periods 1-4), 9 acquired infection with Ps. aeruginosa, but only 4 of these infected patients were at some stage treated with a respiratory ventilator. In most cases, therefore, infection must have come from other sources than the ventilator. A strain of type $B$ was isolated from the tubing of a respiratory ventilator on 4 Jan., 10 days before the first isolation of this type from the trachea of a patient. In this one instance there was circumstantial evidence of infection possibly acquired from a respiratory ventilator. The two other isolates of Ps. aeruginosa from ventilator tubing (table VI) were not typed. In the special series of 166 samples from respiratory ventilators, only one (from a Y-tube of a Smith-Clarke respirator, in Jan. 1966) showed the presence of Ps. aeruginosa.

The following sites were tested but never yielded Ps. aeruginosa: jars of hand cream (16 samples tested), humidifiers of respiratory ventilators (12), curtains (31), resuscitation tubing (12), forceps in dish (5), Ryles' tubes (4), laryngoscope (12), monitor connexions (4), X-ray apparatus (4), plastic disposal bags for dirty linen (3), wall cleaning fluid (1), hand towels (5), $0 \cdot 5,0 \cdot 1$ and 0.02 per cent. stock solutions of chlorhexidine gluconate (8), thermometers in 0.5 per cent. chlorhexidine gluconate (12), stainless steel receivers (13), crockery (27), diet components (4), waste food bin (1), tea towels (2), bed linen (impression plates) (17), bedpan (1), and urine bottles (6). Later sampling (after periods 1-15) showed that 1 out of 5 urine bottles and 3 out of 14 bedpans were contaminated with Ps. aeruginosa.

The frequency of isolation of Ps. aeruginosa from the hands of members of staff, including nurses, doctors, physiotherapists and cleaners, is shown in table VII. During all outbreaks Ps. aeruginosa was found on the hands of some members of staff, sometimes in moderate or large numbers. Nurses usually carried a type that was causing infections in the patients.

\section{Effects of improvements in aseptic technique}

On the basis of findings made during the early periods of the study, some improvements in technique were introduced in order to eliminate the most important sources of infection with Ps. aeruginosa. These improvements were: (1) the use of disposable plastic gloves for bronchial and oral toilet and for as many as possible of the procedures that involved handling the patient, (2) the use of sterile forceps to handle suction catheters during bronchial toilet, (3) the supply of individual plastic washing bowls for patients, (4) the use of 0.5 per cent. chlorhexidine gluconate in place of the 0.02 per cent. solution initially used as disinfectant in collecting bottles and for connexions of suction apparatus temporarily removed, (5) rigorous adherence to the rule that "clean " nursing procedures (e.g., oral toilet) should be carried out before " dirty " procedures, such as the taking of rectal temperatures, and (6) discontinuation of the use of an 
aperture for the end of the suction tubing in the framework carrying the tubing over the bed. These apertures were commonly found to be contaminated

TABLE VII

Isolations of different types of Ps. aeruginosa from the hands of staff, including nurses, doctors, physiotherapists and cleaners, in the Major Injuries Unit

\begin{tabular}{|c|c|c|c|c|}
\hline \multirow{2}{*}{ Period } & \multirow{2}{*}{$\begin{array}{l}\text { Type(s) of Ps. aeruginosa } \\
\text { causing tracheostomy } \\
\text { infection during period }\end{array}$} & \multirow{2}{*}{$\begin{array}{l}\text { Number of members } \\
\text { of staff whose hands } \\
\text { were sampled }\end{array}$} & \multicolumn{2}{|c|}{$\begin{array}{l}\text { Types of } P s \text {. aeruginosa isolated } \\
\text { from hands of staff (and number of } \\
\text { persons from whom isolations were } \\
\text { made) }\end{array}$} \\
\hline & & & in direct plate & $\begin{array}{l}\text { in liquid medium } \\
\text { only }\end{array}$ \\
\hline 1 & A, B & 20 & $\begin{array}{l}\text { A (1) } \\
\text { B (2) }\end{array}$ & $\begin{array}{c}\text { A (2) } \\
\text { B (1) } \\
\text { C (1)* } \\
\text { NT (1) }\end{array}$ \\
\hline 2 & None & 17 & $\begin{array}{l}\mathrm{C}(1)^{*} \\
\mathrm{H}(1)^{*}\end{array}$ & $\ldots$ \\
\hline 3 & B & 57 & $\begin{array}{c}\text { B (2) } \\
\text { C (1)* } \\
\text { NT }(3)^{*}\end{array}$ & $\begin{array}{c}\text { B (3) } \\
\text { NT (1)* }\end{array}$ \\
\hline 4 & None & 23 & C (1)* & $\ldots$ \\
\hline 5 & E & 28 & $\ldots$ & $\begin{array}{l}C(1) \\
E(2)\end{array}$ \\
\hline 6 & None & 16 & $\ldots$ & $\mathrm{A}(1)^{*}$ \\
\hline 7 & $A, F, L$ & 22 & $\begin{array}{l}\text { A }(1) \\
\text { A (1)* } \\
F(1)^{*}\end{array}$ & $\begin{array}{l}\text { A (1)* } \\
\text { F (1) }\end{array}$ \\
\hline 8 & None & 7 & .. & $\ldots$ \\
\hline 9 & $A, G, F, L$ & 14 & $\cdots$ & $\begin{array}{l}A(3) \\
A(1)^{*} \\
D(1) \\
F(1) \\
G(1)\end{array}$ \\
\hline 10 & None & 9 & $G(1)$ & $\ldots$ \\
\hline 11 & $\mathbf{F}, \mathbf{X}$ & 18 & $F(1)$ & $\cdots$ \\
\hline 12 & None & 0 & $\ldots$ & $\ldots$ \\
\hline 13 & $\mathrm{~A}, \mathrm{D}, \mathrm{K}$ & 19 & $\begin{array}{c}\mathrm{K}(1) \\
\mathrm{NT}(1)^{*}\end{array}$ & $\begin{array}{l}\mathrm{D}(1) \\
\mathrm{F}(1) \\
\mathrm{K}(1)\end{array}$ \\
\hline 14 & None & 12 & $\ldots$ & E (1) \\
\hline 15 & $\mathrm{E}$ & 14 & $\ldots$ & $E(1) \dagger$ \\
\hline
\end{tabular}

* Isolation from a cleaner.

$\dagger$ Isolation from a physiotherapist. All other isolations were from nurses.

$\mathrm{NT}=$ Not typed. $\mathrm{X}=$ Uncoded type.

with Ps. aeruginosa. Instead, the tube was allowed to drain into a collecting jar containing 0.5 per cent. chlorhexidine gluconate, which was emptied and replaced with a sterilised jar every day. 
In spite of these improvements, a series of outbreaks of infection took place and the proportion of patients infected in subsequent outbreaks was no smaller than it had been in the early part of the study (table VI). After the introduction of gloves for many nursing procedures, contamination of hands with $P s$. aeruginosa was not appreciably reduced. The failure to control infection by these measures was probably due to lapses in some details of aseptic technique, especially in the wearing of disposable gloves, at times when the Unit was under pressure of work and to the existence of sources of infection, e.g., food, bedpans, urine bottles, and, possibly, air, that were not adequately controlled.

\section{Tests for self-infection}

Rectal swabs were taken from 27 patients on or soon after their admission to the MIU or before the appearance of Ps. aeruginosa in swabs from their tracheostomies. Ps. aeruginosa was isolated from two of the rectal swabs. One of the patients thus found to be carrying $P s$. aeruginosa subsequently acquired tracheal infection with Ps. aeruginosa of a different type. The other patient whose rectal swab showed Ps. aeruginosa did not acquire $P s$. aeruginosa in his tracheostomy. Nine patients also had nasopharyngeal swabs taken on admission, but none of these showed the presence of Ps. aeruginosa. The only evidence of possible self-infection with Ps. aeruginosa in patients with tracheostomy in the MIU was in period 5, when an oral swab showed the presence of the type of Ps. aeruginosa that appeared on the following day in the trachea (see above).

\section{Hazards of infection from blower-humidifiers}

A Vickers blower-humidifier (Feldman and Monro, 1963) was used to deliver warm humidified air to patients with a tracheostomy. On one occasion $P s$. aeruginosa was isolated from the water reservoir, the vaporising chamber, and the proximal and distal ends of the corrugated tubing by which the humidifier was connected with the tracheostomy tube of a patient infected with Ps. aeruginosa. The organism was also found in the water reservoir of a humidifier that was ready for use on a new patient. Contamination with organisms from an infected trachea seemed the likeliest source of Ps. aeruginosa in the humidifier. It could not, however, be assumed that Ps. aeruginosa in a contaminated humidifier standing on the floor would be transferred to the trachea of an uninfected patient. The following tests were made to assess the possibility of such transfer and the chances of a clean humidifier being contaminated by a patient.

A Vickers humidifier found to have Ps. aeruginosa in the reservoir was taken to the laboratory and run for $48 \mathrm{hr}$. Bacteriological samples were then taken from the distal end of the corrugated delivery tube and from the reservoir, but Ps. aeruginosa was not found in either site. Afterwards, $10 \mathrm{ml}$ of an overnight broth culture of Ps. aeruginosa was centrifuged, resuspended in distilled water and diluted in 1 litre of water. The suspension was transferred to the reservoir of the humidifier, which was placed on the floor. The delivery tube rose to a 
level corresponding to the height of a hospital bed and was fixed in a position that allowed a pendant " $U$ " loop to appear near the patient's end of the tube. The humidifier was allowed to work during the day, from 10 a.m. to 4.30 p.m., for 3 consecutive days. On two or three occasions each day the U-loop was raised to allow water that had collected in the tube to run back to the humidifier. Samples were taken for bacteriological examination from the reservoir, the inside of the humidifier, the corrugated tube at the proximal (machine) and distal (patient) ends, and from condensate in a boiling tube attached to the end of the delivery tube. Ps. aeruginosa was found in diminishing amounts in the reservoir on each of the 3 days of the experiment and a very scanty growth was also found on the 3rd day inside the humidifier chamber. The organism was never found in the delivery tubing or in the condensate. In a replicate experiment with another strain, Ps. aeruginosa was found in the reservoir in large numbers on 3 successive days and at the end of a week, but in none of the other sites tested.

In another experiment with a clean humidifier and tubing, $1 \mathrm{ml}$ of a suspension of Ps. aeruginosa (a strain originally isolated from a humidifier) in serum was injected into a glass tube attached to the patient's end of the corrugated delivery tube. The glass tube was plugged with cotton wool at its distal end, and a rubber bulb attached to a tracheostomy connexion from one side of the tube was squeezed several times a day to simulate a patient's coughing. The machine was run continuously for $8 \mathrm{hr}$ on each of 3 consecutive days. Bacteriological samples were taken each day from the tubing, the humidifier and the reservoir of the humidifier. Ps. aeruginosa was found in the delivery tube near the humidifier in small numbers on the first 2 days and in large numbers on the 3rd day. Smaller numbers were present in the distal (patient) end of the tube. On the 3rd day Ps. aeruginosa was found in very small numbers in the reservoir of the humidifier, During use, the temperature of the porcelain vaporising block in the chamber of the humidifier rose to $60^{\circ} \mathrm{C}$, at which most vegetative organisms were rapidly killed.

These results suggest that an infected patient could contaminate the reservoir of a humidifier used for his treatment, but a contaminated reservoir is unlikely to infect a patient directly. Indirect contamination, e.g., through contamination of nurses' hands, could, however, be a cause of infection.

\section{Discussion}

The outbreaks of infection with Pseudomonas aeruginosa reported in this paper were shown by the typing of a large number of the strains to be independent episodes caused by one or more strains that were usually distinct from those causing the previous outbreaks. The typing of strains from patients and the environment also gave evidence of possible sources of infection in each outbreak and possible routes of transfer during outbreaks. No single or predominant source could be identified. One infection was brought into hospital by a patient, another was possibly acquired from a nurse's hands on which the infecting type of organism was found before the outbreak. In other outbreaks it seemed 
that infection may have been acquired from patients in another ward, perhaps being transferred by a physiotherapist, or from the inanimate environment of the Major Injuries Unit. With one possible exception, no evidence of selfinfection was obtained. In most patients, rectal swabs taken on admission did not yield Ps. aeruginosa, and in the cases in which Ps. aeruginosa was present, either the strains were of different type from those that subsequently caused infection of the trachea or the trachea did not become infected. In almost all patients, the type causing infection of the trachea was found in other patients or in the hospital environment, and it seems unnecessary to postulate selfinfection. However, the possibility of self-infection cannot be excluded, since Ps. aeruginosa can be isolated from the faeces (Lowbury and Fox, 1954; Shooter et al., 1966) and the saliva (Sutter, Hurst and Landucci, 1960) of many subjects. One patient in our series may have acquired the infecting strain from his saliva, though the organism was not found in the saliva on admission.

Many environmental reservoirs were found. During outbreaks, both the inanimate environment and the hands of nurses often showed strains of types causing current infection, but much smaller numbers were present between outbreaks. Exceptions were the wash-hand basins and other sinks, many of which carried Ps. aeruginosa at all times. Kohn (1966) has reported an association between the types of $P$ s. aeruginosa in sinks and those in burns in a hospital burns unit. In our experience sinks carried an endemic strain of a type that rarely caused infection, but they also showed the transient presence of strains that were causing current infection in patients and which were presumably acquired from these patients. We inferred that sinks were rarely a source of infection in the Major Injuries Unit.

Although respiratory ventilators were used on some patients, and sometimes showed contamination of tubing with Ps. aeruginosa during outbreaks, the humidifiers of ventilators were not found to be contaminated with Ps. aeruginosa and the organism was not found on the tubing between outbreaks. This equipment cannot be counted among the more important sources of infection in the MIU, though in one period the infecting type of Ps. aeruginosa was found in the tubing of a respiratory ventilator before it appeared in a patient's trachea. Blower-humidifiers were often found to be contaminated, but attempts in the laboratory to detect these organisms in the effluent of air from the distal end of the delivery tube were unsuccessful. The sources that seemed particularly important were the hands of nurses, physiotherapists and other members of staff, on which the infective strains were often found, and the communal plastic washing bowls that were used in the earlier part of the study. Ps. aeruginosa of the infective types were often found in these bowls when they were ready for use by patients. Many other reservoirs of the bacteria were found, including food and food mixers, which were potentially important (McLeod, 1958), and floors, which were probably not important (Ayliffe et al., 1967). Air was rarely found to be contaminated with Ps. aeruginosa, and the numbers of the bacteria present in it were extremely small. Aspirator bottles used in the suction apparatus were contaminated, in spite of the presence of 0.5 per cent. chlorhexidine. Mackley filters (Marshall, 1964) were 
used between the aspirator bottle and the oxygen suction pump, but fluid was occasionally sucked into the filter, and bubbles contaminated with $P s$. aeruginosa were found at the vent holes of the suction pump.

Control of infection with Ps. aeruginosa in such an environment involves two factors: (1) exclusion of the pathogen from the environment and (2) prevention of the transfer of the pathogen from infected to uninfected patients in the ward. In this study some series of patients with tracheostomies (e.g., 13 during period 6) remained free from $P_{s}$. aeruginosa, suggesting that exclusion of the organism from the environment was sometimes very successful. When infection took place, however, it was usual for most, if not all, of the other patients in the ward with tracheostomy to become infected. Often the same type of pseudomonas appeared in different patients, e.g., in periods 1, 7 and 11, but sometimes different types appeared, suggesting an inadequacy of the aseptic barriers to cope with an exceptional hazard of contamination and colonisation.

Attempts to control infection by blocking some of the sources of Ps. aeruginosa revealed in this study have so far been unsuccessful. The use of disposable plastic gloves or sterile forceps for many nursing procedures formerly done with the ungloved hand was expected to lead to less infection with Ps. aeruginosa and to less frequent isolation of the organism from nurses' hands. The results, however, were disappointing, undoubtedly because of other deficiencies in the aseptic techniques, e.g., the failure to disinfect urine bottles, bedpans and crockery, and lapses in performance of asepsis at exceptionally busy times or when staff was short. In particular, the compromise, in nursing procedures other than bronchial toilet, of using gloves only for patients already infected with Ps. aeruginosa exposed the uninfected patients to the risk of contamination. The infection might come from the hands of nurses, physiotherapists and others who had acquired the bacterium from other wards or from the inanimate environment of the MIU.

In a continuation of the study an attempt is being made to prevent crossinfection with $P$ s. aeruginosa by improvements in aseptic methods and by a more strict discipline of glove technique for all patients with tracheostomies, as well as for all patients known to be infected with Ps. aeruginosa. It is important that the staff handling patients with tracheostomies should be familiar with the details and rationale of the aseptic measures in use and that there should be enough nurses to ensure that as much as possible of the aseptic routine can be applied at all times. The technique should be consistent, and practicable for available staff at all times. Insertion of endotracheal tubes by anaesthetists with ungloved hands is another way in which the trachea may become contaminated with Ps. aeruginosa and other hospital organisms. It is important that all members of the staff-doctors, physiotherapists and laboratory workers as well as nurses-should adhere to the recommended procedure.

The wearing of disposable gloves and the use of forceps for handling endotracheal catheters not only protects the patient against contamination from the nurse's hands, but also protects the nurse against infection with organisms acquired from patients. Stern et al. (1959) described outbreaks of whitlows on 
the hands of nurses due to infection with herpes virus associated with the handling of tracheostomy tubes. Infection and colonisation of the skin with Staphylococcus aureus may also be caused by handling contaminated secretions.

\section{SUMMARY}

Over a period of $20 \mathrm{mth}$ all the patients with tracheostomy in an intensive care unit for major injuries were examined frequently, often daily, for the presence of Pseudomonas aeruginosa in the tracheal mucus. During the same period the hands of staff and the inanimate environment in the Unit were examined weekly for the presence of Ps. aeruginosa. Numerous isolates of Ps. aeruginosa from these sources were typed by phage and serological methods.

Eight outbreaks occurred in which patients had infection with $P$ s. aeruginosa in the trachea, and there were seven periods between outbreaks when $P$ s. aeruginosa was not found in samples from tracheostomies. Strains of $P$ s. aeruginosa isolated in successive outbreaks were of different types. Strains isolated from the environment were usually of types already present in tracheostomies. More rarely strains of types already present in the environment were subsequently found in tracheostomies. There was no endemic infecting strain in patients, though a single type was isolated from sinks, as well as strains of other types that were transient, throughout almost the whole period of the study. This strain from sinks caused infection in patients during four of the eight outbreaks, but was not the first strain to cause infection except in the first outbreak.

Of the numerous sources from which Ps. aeruginosa was isolated, and from which patients might become infected, the hands of nurses, physiotherapists and other members of staff seemed to present a special hazard of transferring infection. Other potentially important sources were plastic washing bowls, food and food mixers, and suction apparatus. Many sites commonly associated with Ps. aeruginosa contamination, e.g., nailbrushes, dishcloths, floors and floor mops, sinks and sink mops, were found to be contaminated. Samples of air occasionally yielded a few Ps. aeruginosa. Respiratory ventilators were used on some of the patients who became infected with Ps. aeruginosa, but the evidence suggested that these were not an important source of infection. Blower-humidifiers sometimes became contaminated, but experimental study of this equipment suggested that it was not a likely source of infection. Selfinfection may have occurred in one patient.

A number of recommendations were made, including the use of disposable plastic gloves for a wide range of nursing procedures, the supply of individual plastic washing bowls disinfected daily, and improvements in the arrangement for suction. Sometimes infection seemed to be due to lapses in technique caused by ignorance or by pressure of work. Prevention of infection of tracheostomies remains a challenge to vigilance and discipline.

We wish to thank the surgeons, Sisters and nurses at the Birmingham Accident Hospital, and $\mathrm{Mr}$ W. Cater, Instrument Curator, for their valuable cooperation. 


\section{REFERENCES}

Alder, V. G., Brown, A. M., ANd Gil- 1966. J. Clin. Path., 19, 83. LESPIE, W. A.

AylmfF, G. A. J., Collins, B. J., Low- 1967. J. Hyg., Camb., 65, 515. BURY, E. J. L., BABB, J. R., AND LILLY, H. A.

BishOP, C.

1966. Lancet, 1, 267.

Bishop, C., Potts, M. W., AND Molloy, 1962. Br.J. Anaesth., 34, 121. P. J.

Brown, V. I., And Lowbury, E. J. L. . 1965. J. Clin. Path., 18, 752.

Dupont, V., Lissac, J., AND Amstutz, P. 1962. Revue Pratn, 12, 1909.

Feldman, S. A., AND Monro, J. A. . 1963. Br. Med.J., 2, 612.

Gotsman, M. S., AND WhitBY, J. L. $\quad$. 1964. Thorax, 19, 89.

HaBs, I.

Judd, P. A., Tomlin, P. J., WhitBy, J. L., INGLIS, T. C. M., AND ROBERTSON, J. S.

KoHN, J.

1957. Z. Hyg. InfektKrankh., 144, 218.

1968. Lancet, 2, 1019.

1966. In Research in burns, ed. by A. B. Wallace and A. W. Wilkinson, Edinburgh and London, p. 486.

LONDON, P. S.

Lowbury, E. J. L., AND Fox, J. . 1954. J. Hyg., Camb., 52, 403.

LowBURY, E. J. L., AND LILLY, H. A. $\quad$. 1960. Br. Med. J., 1, 1445.

Lowbury, E. J. L., Lilly, H. A., AND 1962. J. Clin. Path., 15, 339. WILKINS, M. D.

MCLEOD, J. W.

MARSHALL, $M$.

1958. Lancet, 1, 394.

1964. Ibid., 2, 21.

Phillips, I.. ～～～～～～～～1967. J. Hyg., Camb., 65, 229.

Phillips, I., AND SPencer, G. - . 1965. Lancet, 2, 1325.

ShOOTER, R. A., WAlker, K. A., WIL- 1966. Ibid., 2, 1331. Liams, Veronica R., Horgan, Gillian M., PARKer, M. T., Asheshov, ElizaBETH H., AND BULlIMORE, JULIET F.

Stern, H., Elek, S. D., Millar, D. M., 1959. Ibid., $2,871$. AND ANDERSON, H. F.

Sutter, Vera L., Hurst, Valerie, GrossMAN, M., AND CALONJE, R.

Sutter, Vera L., Hurst, VAlerIe, AND 1960. J. Dent. Res., 45, 1800. LaNDUCCI, A. O. J.

Tinne, J. E., Gordon, A. M., Bain, W. H., 1967. Br. Med. J., 4, 313. and MacKay, W. A.

Verder, E., ANd EvaNs, J. · • 1961. J. Infect. Dis., 109, 183.

VÉRON, M. .

1961. Annls Inst. Pasteur, Paris, 101, 456.

WaHBA, A. H. - $\quad$. $\quad$ - $\quad$. $\quad$. 1965. Br. Med. J., 1, 86.

WATTS, J. MCK. . . 1964. In Recent advances in surgery, 6th ed., edited by S. Taylor, London, p. 143. 